\title{
Barns kommunikation och lärande i fysik genom praktiska experiment
}

\begin{abstract}
Physics is often considered to be a difficult, abstract and boring school subject. This article describes a study of 11-year old children's discussions of scientific concepts related to experiments in the classroom and to the Liseberg amusement park. The study was made in May 2004 and the empirical material consists of tape recorded group discussions from the preparation lesson before the amusement park visit. The analysis focuses on how children use, develop and verify their knowledge, and how they express an increased construction of knowledge and understanding through the dialogues. The discussions indicate an ability to develop, explain and exemplify physical phenomena and concepts and connect them to their everyday experiences.
\end{abstract}

\section{INLEDNING}

Forskning om undervisning och attityder, allmänna undersökningar och utbildningsstatistik visar att allt färre elever visar intresse för naturvetenskap och teknik (Lindahl, 2003; Schreiner \& Sjöberg, 2004). Genom att introducera naturvetenskap i tidig ålder och på ett spännande sätt kan eleverna utveckla en mer positiv attityd till ämnet. Syftet med denna artikel är att beskriva hur 11-åringar inför en experimentdag på nöjesparken Liseberg resonerar i samband med experiment $\mathrm{i}$ klassrummet relaterade till åkattraktionerna, samt hur det genom den språkliga kommunikationen utvecklas ett samspel mellan den enskilde individens föreställningar och vad de andra säger. På vilket sätt diskuterar barnen experimenten och relaterar dessa till egna upplevelser, erfarenheter och för dem kända vardagsfenomen?

Analysen fokuserar på gruppdiskussionerna vid klassrumsexperimenten, men besöket på Liseberg är för barnen en gemensam motiverande faktor i diskussionen, och det faktum att de flesta barnen redan besökt Liseberg i andra sammanhang hjälper dem då de skall utföra sina tankeexperiment. Eleverna använder ett sätt att resonera och förklara för varandra där de använder sig av exempel och motexempel och relaterar till såväl tankeexperiment på Liseberg som till genomförda experiment i klassrummet.

Lärande i skolan bygger på elevers kommunikation med läraren och med varandra, och sker genom deltagande i en praktik (Lave, 1997; Rogoff, 2003; Wenger, 1998). Den sociala gruppen och den kommunikativa gemenskapen som eleven tillhör, är en viktig utgångspunkt för lärandet och samspelet mellan människor i en lärandekontext är avgörande både för vad som lärs och hur det lärs. Språk och kommunikation är inte enbart instrument för lärande utan också det grundläggande villkoret för lärande och tänkande och därmed en länk mellan kulturen och människans tänkande. 
Naturvetenskaplig undervisningen i skolan strävar oftast efter vetenskapliga förklaringar vilka ofta bygger på formella, ibland matematiska konstruktioner. För att eleverna skall kunna tillgodogöra sig dessa förklaringar av vetenskapliga begrepp är det också viktigt att dessa kan relateras till för dem kända fenomen. Om man jämför med den mängd forskning som gjorts om barns begreppsbildning i naturvetenskap, är forskningsfältet om hur barns förmåga att resonera runt dessa dåligt representerat (Tytler \& Peterson, 2003). Det finns ett behov av forskning som klargör olika dimensioner av naturvetenskapligt resonemang, däribland hur elever samverkar samt hur de skall uppmuntras för att bättre utveckla sitt resonemang. Barns naturvetenskapliga resonemang kan karaktäriseras av olika dimensioner vilka t. ex. inkluderar deras försök till förklaringar där deras begreppskunskap interagerar med deras vetenskapliga resonemang på många olika sätt (Tytler \& Peterson, 2003; Gunstone \& White, 1981).

\section{BEGREPPSBILDNING OCH LÄRANDE}

Området naturvetenskaplig begreppsbildning har producerat mängder av forskningsrapporter sedan Piaget började sina studier av barns tänkande och studier av elevers "misconceptions" är vanligt förekommande (Andersson, 1989; Clement, 1982; Driver, 1985; Driver, Squires, Rushworth \& Wood-Paulson, 1994; Hart, 2002; Helldén, 1992). Begrepp är nödvändiga då något skall förklaras eller bevisas och att analysera användandet av begrepp relaterat till en kontext som inte är den vanliga skolkontexten är intressant ur flera perspektiv. Att förklara är att utreda något så att det kan förstås av någon annan.

Vygotsky (1934/1986) menade att eleverna lär sig vetenskapliga begrepp genom att uppmärksamma den spänning som finns mellan deras eget vardagstänkande och en mer kompetent persons föreställningar och uppfattningar. Vardagsbegrepp är spontana begrepp som kommer från barnens egna livserfarenheter men vetenskapliga begrepp är klassifikationer utifrån en abstrakt förståelse. I skolan sker begreppsbildningen uppifrån och ned då barnet möter olika begrepp, termer och modeller och genom att arbeta sig ned till konkreta iakttagelser och erfarenheter lär de sig successivt vad de betyder. Vardagliga förklaringsformer ställs mot vetenskapligt grundade begrepp och eleverna skall försöka förstå och tillgodogöra sig den abstrakta diskurs som skolans naturvetenskap ofta kan utgöra.

Andersson (2001) beskriver systemskillnader mellan vardagligt och vetenskapligt tänkande där vardagstänkandet är t.ex. omedvetet, situationsbundet och ställer mindre krav på inre sammanhang och logik. Det vetenskapliga tänkandet är t.ex. medvetet, generellt och systematiskt organiserat. Sjöberg (2000) diskuterar vardagens språk och vetenskapens språk och menar att vissa av de ord som vetenskapen använder är hämtade från vardagsspråket men deras betydelse ändras då de sätts i ett vetenskapligt sammanhang. Några exempel på sådana ord är kraft, värme och energi som får en helt annan betydelse $\mathrm{i}$ ett vetenskapligt sammanhang än i ett vardagssammanhang. Vetenskapen använder ord från vardagen men har också tvingats utveckla egna begrepp och ord som bara har betydelse där. Om ord som t.ex. protoner skall få en betydelse måste de knytas till existerande begrepp på ett meningsfullt sätt (Sjöberg, 2000).

Barn utvecklar begrepp om saker, händelser och företeelser i vardagen utifrån sin kulturella och sociala omgivning. Denna kunskap bygger då till stor del på erfarenheter och egna upplevelser. Exemplet att "en sten faller till marken då vi tappar dem" är en vardagskunskap som alla som någonsin tappat ett föremål känner till. Tappar vi något tungt på foten gör det dessutom ont, ytterligare en vardagskunskap som bygger på erfarenhet. Vardagskunskapen kan alltså vara rent personlig och användbar i olika situationer i livet. Barnet behöver inte känna till begreppet gravitation för att beskriva vad som händer med stenen då det tappar den. Vetenskapliga begrepp är av en helt annan karaktär och vi möter dem oftast i faktaprogram, undervisningssituationer m.m. De uppkommer som ett resultat av människors tankar och kunskapssökande för att teoretiskt förstå 
samband och sammanhang som inte alltid förklaras utifrån vardagliga erfarenheter. De vetenskapliga begreppen är konstruerade av människor på ett formellt sätt och utgörs ofta av teoretiska modeller och definitioner. De är konstruerade av människan som redskap för att förstå världen, och de kan vara mer eller mindre lämpade för ett bestämt ändamål (Sjöberg, 2000). Gränsdragningen mellan vardagliga och vetenskapliga begrepp är ibland mycket svår.

\section{Kommunikation av vetenskapliga begrepp}

Lärandet är inte endast en process att ackumulera kunskap utan också en process att inlemmas i en lärandegemenskap där lärandet definieras som ett utbyte där förståelse skapas i dialog med andra (Falk, Donovan \& Woods, 2001). Lemke (1990) talar om tekniska mönster som bestämmer hur begrepp skall användas och inom vilka diskursiva ramar man skall hålla sig för att föra diskussionen framåt. I detta sammanhang räcker det inte att veta betydelsen av varje enskild term. Man måste också känna till hur dessa termer relaterar till varandra och till andra termer och begrepp i den speciella diskursen (Engeström, 1977; Lemke, 1990). Då naturvetenskapliga termer och begrepp används som redskap i diskussioner kan förståelsen av dessa synliggöras i diskussionen. Ett samtal är en situation där man lär och där kunskaper ständigt formuleras om och sätt in i ett nytt sammanhang. Säljö och Wyndman (2002) diskuterar begreppsbildning ur ett sociokulturellt perspektiv och menar att tillägnandet av ett begrepp kan förstås som en individs ökande förtrogenhet med begreppets innebörd och användningsområde. Det är i interaktion och diskussioner som vi blir bekanta med och som vi lär oss att använda främmande begrepp. Säljö (2000) betonar tänkandets kommunikativa och kollektiva karaktär. I denna studie resonerar eleverna om klassrumsexperiment och använder sig av olika begrepp och termer, för att kunna förklara och beskriva naturvetenskapliga fenomen.

Forskning visar att elever ofta har svårigheter att använda naturvetenskapliga termer och begrepp. De använder ofta endast termen för ett fenomen som en korrekt förklaring (Schoultz, 2000). Under senare år har diskursiv och sociologisk psykologi påverkat forskning om lärande i naturvetenskap och därmed utvecklat ett ökat intresse för studier om hur mening utvecklas genom språket i klassrummet. Vilken betydelse spelar då användandet av vetenskapliga termer och begrepp för en grupps kunskapsbildning och vilka termer och begrepp är rimliga för ett barn att uppfatta vid en viss ålder?

\section{STUDIENS GENOMFÖRANDE}

Liseberg är Skandinaviens största nöjespark och sedan 1995 har studier av Lisebergs attraktioner använts i fysikkurser och lärarutbildningskurser vid Göteborgs Universitet. Mellan åren 2000-2004 har 9000 skolelever i olika åldrar experimenterat i några av attraktionerna (Bagge, 2003; Bagge \& Pendrill, 2002; Nilsson, Pendrill \& Pettersson, 2004). Tidigare erfarenheter av Lisebergsprojektet har visat att resultatet av lärande i fysik i en nöjesparkskontext beror på hur väl förberedda barnen är före besöket (Nilsson, $\mathrm{m} \mathrm{fl,} \mathrm{2004).} \mathrm{Ett} \mathrm{antal} \mathrm{experiment} \mathrm{relaterade} \mathrm{till} \mathrm{attraktionerna} \mathrm{på} \mathrm{Lise-}$ berg genomfördes därför några dagar före besöket. Lektionen planerades och genomfördes av två lärarstudenter och målet var att introducera ämnesområdet mekanik, samt att få eleverna att resonera runt olika fysikaliska fenomen. Det planerade temat i mekanik skulle efter Lisebergsbesöket avslutas med en lektion där upplevelser och erfarenheter skulle diskuteras.

Barnen delades upp i fyra grupper med sex till sju elever i varje grupp och cirkulerade runt mellan de olika stationerna. Vid varje station låg ett papper med frågor som barnen skulle diskutera samt ett praktiskt experiment som de skulle genomföra. Stationerna behandlade i första hand begrepp så som gravitation, tröghet, rotation, acceleration, kraft och hastighet. Barnen diskuterade frågorna samt sina hypoteser före experimentet och förväntades sedan förklara resultatet av det genomförda experimentet. 
Vid den första stationen skulle eleverna besvara frågorna Vem når marken först av Nalle Puh och Nasse om de hoppar från ett tak på samma gång? Varför faller saker till marken då vi tappar dem? Varför faller inte månen ned på marken? Vid stationen fanns två lika stora PET-flaskor. En fylld med vatten som skulle illustrera Nalle Puh och en tom som skulle illustrera Nasse. I denna artikel analyseras i första hand diskussionerna vid denna station.

Vid den andra stationen skulle barnen besvara frågorna Vad händer med din kropp om du krockar rakt framifrån, bakifrån och från sidan med din kompis i radiobilarna? Experimentet demonstrerade begreppet tröghet kopplat till radiobilarna genom att barnen fick krocka leksaksbilar med föremål på taket. Vid den tredje stationen skulle barnen diskutera hur en slinky (liten plastspiral) ser ut i olika lägen samt vad som händer med slinkyn i åkattraktionerna. Den fjärde stationen illustrerade rotation med hjälp av ett cykelhjul och en pendel.

\section{ANALYS AV KOMMUNIKATION OCH LÄRANDE I SMÅ GRUPPER}

Detta arbete presenterar en analys av kommunikationen mellan eleverna i gruppen som en situerad sociokulturell praktik där begrepp används, relateras till vardagliga företeelser och utvecklas i samtal. Eleverna har ingen tidigare erfarenhet av mekanik i undervisningen, men har under en tid arbetat experimentellt inom andra områden. Därför är det naturvetenskapliga arbetssättet med t.ex. hypotestänkande inte främmande för dem. Däremot har de ingen vana $i$ att resonera och diskutera runt experiment på det sätt som görs i denna studie. Eleverna befinner sig den största delen av tiden ensamma och diskuterar fritt runt experimenten. Den fria diskussionen tillåter en bättre analys av hur eleverna verkligen resonerar kring begreppen än om läraren hade styrt diskussionen. Deras gemensamma vardagserfarenheter och förväntningar speglas i deras diskussioner, där ett av syftena är just att resonera om den fysik som kan upplevas och läras på Liseberg. Det empiriska materialet består av video och kassettbandinspelningar av gruppdiskussioner vid det förberedande experimentpasset före Lisebergsbesöket.

I analysen av gruppdiskussionerna används en modell som utvecklats av Barnes och Todd (1977) där kommunikation och lärande i små grupper analyserats i två nivåer, och som bygger på studier av 11-åringars samtal inom olika ämnesområden utifrån ett antal förutbestämda frågor och påståenden. Den första nivån fokuserar på vad som karaktäriserar samtalen med avseende på turtagning och samspel mellan individerna och den andra nivån fokuserar på gruppmedlemmarnas reflektion och kognitiva utveckling.

I min analys har använt mig av en kategori i nivå två kallad kognitiva strategier, där gruppens förmåga att resonera analyseras. Jag studerar hur de diskuterar experimenten och relaterar dessa till egna upplevelser, erfarenheter och för dem kända vardagsfenomen. Jag studerar också hur de i sina samtal för in olika termer och exempel, som kan spåras till andra fysikaliska fenomen än just de som efterfrågas i experimentet. De kognitiva strategierna delas upp i fem kategorier: Konstruera frågan: För att kunna svara på frågan var de ibland tvungna att rekonstruera frågan genom att använda det de redan visste för att göra frågan meningsfull. Väcka nya frågor: Illustrerar det sätt på vilket barnen kan gå utanför de givna ramarna och ställa användbara frågor för att skapa förståelse. Ställa upp hypoteser: Eleverna ställer upp nya hypoteser utöver den givna informationen för att få fram en förklaring eller en tolkning. Använda bevis: En viktig kognitiv strategi är att kunna använda tidigare kunskaper och erfarenheter som en tillgång, att använda vardagskunskaper, konstruera hypotetiska fall och att använda information för att utmana påståenden. Uttrycka känsla och återskapa erfarenheter: Vissa ämnen som diskuterades i gruppen låg så nära elevernas egna intressen att de skapade ett känslomässigt engagemang hos eleverna. Denna kategori representeras av de uttryck där eleverna relaterar och associerar fenomenet till en tidigare erfarenhet, en observation av experiment eller upplevelse på Liseberg. 


\section{ANALYS OCH RESULTAT - ELVAÅRINGARS KOMMUNIKATION OCH LÄRANDE AV FYSIKALISKA BEGREPP}

I analysen av 11-åringars gruppdiskussioner studeras de kognitiva strategierna vid en av experimentstationerna nämligen den om Nalle Puh och Nasse. Syftet med denna begränsning är att jag är intresserad av på vilket sätt eleverna i diskussionen relaterar de vetenskapliga begreppen gravitation, densitet, luftmotstånd till vardagserfarenheter, samt hur de olika individerna i gruppen resonerar om experimentet och förklarar fenomen för varandra. Gruppdiskussionerna vid klassrumsexperimenten före Lisebergsbesöket har transkriberats och de samtal som är av intresse för experimentet har valts ut för analys. Detta urval är gjort utifrån författarens bedömning om i vilken grad diskussionerna representerar de av Todd och Barnes uppställda kategorierna i de kognitiva strategierna. Med avseende på urvalet av analyserade transkript kan studiens validitet och reliabilitet komma att ifrågasättas, men då samtliga grupper förde engagerade diskussioner behövde inte urvalsprocessen bli särskilt problematisk. De transkript som redovisas för analys är representativa för de fyra elevgruppernas diskussioner. Eleverna i gruppen har identifierats för att det skall vara möjligt att även följa elevernas samtal på individnivå. Genom att visa vilken medlem i gruppen som kommer med vilket uttalande är det möjligt att studera mönstret i tankeutvecklingen $\mathrm{i}$ en diskussion, och också vilket stöd de ger varandra.

\section{Analys av kognitiva strategier i gruppdiskussionerna}

I kognitiv inlärningsteori är lärande en aktiv konstruktionsprocess där eleverna tar emot information, tolkar den, knyter ihop den med vad de redan vet och om så krävs omorganiserar de mentala strukturerna så att den nya förståelsen skall passa in (Dyste, 2003). Vid en analys av de kognitiva strategierna studeras gruppens kommunikation och lärande genom de praktiska experimenten.

I följande transkript analyseras de kognitiva strategierna i elevernas diskussioner om Nalle Puh och Nasse. Då de olika kategorierna är svåra att urskilja och separera i diskussionerna har jag valt att inte behandla varje kategori för sig själv utan i stället lyfta fram de delar av diskussionerna som visar hur eleverna bearbetar frågorna, vilka begrepp de för in och använder i sina diskussioner, hur de relaterar vetenskapliga begrepp till vardagssituationer samt i vilken utsträckning de applicerar begreppen på experimenten och relaterar till erfarenheter och till tankeexperiment.

\section{Grupp 1 Gravitation och luftmotstånd}

Gruppen diskuterar varför saker faller till marken då vi tappar dem:

Håkan: Det är gravitationen... eller vad det heter. Det är något om gravitation och G-krafter...någonting på jorden som gör att man...de åker ändå lika snabbt ned?

Sara: Vad är gravitation?

Håkan: Det vet jag...

Sara: Varför faller saker till marken då du tappar dem?

Malin: Dragningskraften

Håkan: Tyngdkraften alltså.

Sara: ̈̈r tyngdkraft och dragningskraft det samma?

Julia: Jag vet inte. Skall man skriva slutsats eller.

Håkan vidareutvecklar resonemanget om begreppen gravitation och G-kraft genom att exemplifiera att saker åker ned, vilket visar på att han kopplar begreppet gravitation till ett vardagsfenomen där han av erfarenhet vet att saker faller ned. Han återskapar en erfarenhet om att de åker lika snabbt ned, men har svårt att förklara detta fenomen. Sara kommer in i samtalet och väcker en fråga för att klargöra sin uppfattning om vad gravitation är. Eleverna har nu börjat resonera runt fyra begrepp: dragningskraft, tyngdkraft, G-kraft och gravitation. Fler och fler elever deltar i diskussionen och de olika begreppen diskuteras i förhållande till vardagserfarenheter. De använder vardagserfarenheter som en tillgång för att konstruera hypotetiska fall och att använda information 
för att utmana påståenden. Diskussionen visar hur ett barn för in ett begrepp som sedan diskuteras vidare och ifrågasätts av de andra. Julia kommer in i diskussionen med frågan om man skall skriva hypotes, vilket visar att hon är i en skoldiskurs där det är viktigt att skriva slutsatser.

\author{
Emil: Vilken faller först till marken av Nalle Puh och Nasse? \\ Julia: Ingen aning \\ Emil: Jag tror faktiskt nasse för han är lättast. \\ Sara: Lika snabbt för tyngden har ingen betydelse. \\ Göran: Den tyngsta faller fortare. \\ Julia: Den tyngsta. (hakar på!) \\ Emil: Jag tror att den som är lättast. \\ Håkan: Tyngden har ingen betydelse tror jag. \\ Göran: Det tror jag.
}

Emil kommer in i diskussionen och återkallar uppmärksamheten till frågan. Han har suttit tyst under föregående diskussion men börjar här resonera om vem som faller först. Hans förslag på att Nasse faller först för att han är lättast bygger på en vardagsföreställning om att lätta saker faller långsammare än tunga. Sara vidareutvecklar diskussionen och ställer upp en hypotes om att de når marken samtidigt eftersom inte tyngden har någon betydelse. I detta påstående får hon stöd från Håkan som var den som ställde denna hypotes i början av diskussionen. Eleverna har här genom att resonera och diskutera sina hypoteser nått en nivå i diskussionen där det rätta svaret, dvs. att de faller samtidigt förespråkas av två av eleverna.

Mimmi: Den som är lättast, det blir typ som ett luftmotstånd när den ramlar ned. Nasse är minst och han får minst luftmotstånd.

Håkan: Den som är bredast, Nalle Puh, Han får mer luft emot sig.

Göran: Han är ju tyngre också så han faller ju snabbare.

Mimmi: Den som är lättast kommer först. (släpper ett papper). Nasse ramlar först. Han har minst luftmotstånd.

Göran: Jag vet. Vi släpper båda och det är vatten i den ena alltså är den tyngre...så ser vi.

Mimmi för in begreppet luftmotstånd och utökar därmed resonemanget. Barnen kommer här in i en ny diskussion om på vilket sätt luftmotståndet relateras till föremål som ramlar ned. Ett resonemang om luftmotståndets betydelse kopplas till vardagserfarenheten om att föremål ramlar ned då de släpps. Göran och Mimmi står fortfarande fast vid sin felaktiga vardagsföreställning där de tror att de kommer att falla till marken vid olika tillfällen. Däremot resonerar Mimmi om luftmotståndets betydelse vilket är av stor vikt eftersom i tankeexperimentet med den riktige Nalle Puh och Nasse är Nalle Puh större och får ju också större luftmotstånd. Göran vill använda det planerade experimentet som bevis, han är medveten om att den ena flaskan är tyngre men att de ser likadana ut har de också samma luftmotstånd. I detta resonemang kan man spåra ett variabeltänkande där en variabel är konstant (luftmotståndet) och en är varierande (massan). Eleverna testar nu experimentet genom att släppa de båda PET-flaskorna och alla förvånas över att de når marken samtidigt.

Alla: Samtidigt.

Håkan: Tyngden gör ingen förändring.

Emil: De VAR lika. (Förvånat). Jag tror faktiskt att det är tyngd....

Mimmi: Jag vet inte varför.

Julia: Tyngdkraften.

Göran: Resultatet blir att de faller samtidigt på grund av dragningskraften.

Mimmi: Luftmotståndet då? 


\section{Pernilla Nilsson}

Håkan: Det är... de har ju lika luftmotstånd för att de är lika stora och ser likadana ut. Mimmi: (Sitter och testar hela tiden med sitt suddigum som hon släpper för att se vad som händer). Man faller inte så fort om man har fallskärm för att då blir det ju luft under... Alltså luftmotstånd.

Med hjälp av att använda bevis och återkalla till experimentets utfall ändrar nu eleverna sitt resonemang. De är alla överens om att flaskorna nådda marken samtidigt, men söker en förklaring till det inträffade. Håkan och Göran påpekar att tyngden inte gör någon skillnad eftersom dragningskraften gör att de faller samtidigt. Mimmi som fortfarande söker en förklaring kopplad till luftmotståndet vill återkomma till detta genom att ställa en ny fråga. Detta gör att Håkan relaterar här storleken på det fallande föremålet till luftmotståndet och förstår att eftersom flaskorna ser exakt likadana ut så har de också samma luftmotstånd. Begrepp luftmotstånd diskuteras och relateras till en verklighet samt till experimentet. Mimmi resonerar vidare om begreppet luftmotstånd och exemplifierar detta genom att koppla det till en vardagserfarenhet, fallskärmen.

\section{Grupp 2 . Kanonkulor, stenar och liggande flaskor}

Följande transkript visar hur barnen relaterar begreppen till olika tankemodeller:

Mattias: Men detta är ju ingen kanonkula och sten. Detta är Nalle Puh och Nasse.

Bob: Men det är samma lufttryck Nasse är lättare och Nalle Puh är större.

Pernilla: Jag tror ändå att det är Nasse.

Lotta: Jag tror faktiskt att det kan vara så. Det går ju snabbare. Nalle Puh är tyngre och ni sade ju Nasse... då borde det ju gå lika fort.

Mattias: Men om man skjuter en kanonkula rakt upp och om man skjuter en sten rakt upp. Stenen går fortare rakt upp. Kanonkulan går fortare ned för att den stannar mycket snabbare.

Lotta: Jag tror att de är lika.

Pernilla: Skall vi skriva att de faller samtidigt.

Gruppen har hittat en strategi att lösa problemet och samarbetar i diskussionen då de resonerar om lufttryckets relation till Nalle Puh och Nasses massa. Bob introducerar resonemangen om tyngd och lufttryck och Lotta samt övriga hakar på detta resonemang. Modeller så som kanonkulan och stenen förs in i samtalet för att utvidga diskussionen och exemplifiera resonemanget. Diskussionen avslutas med att alla är överens om att "Nalle Puh han är tung och Nasse är liten och får mindre lufttryck. Nalle Puh är tyngre och därför faller han snabbare."

Vem når marken först av Nalle Puh och Nasse?

Alla: Samtidigt.

Mattias: Men vänta! De är ju lika stora!

Lotta: Ja men den är ju tyngre!

Mattias: Ja men de är ju ändå lika stora och kommer ned samtidigt. Denna är ju inte mindre eller någonting.

Lotta: De har samma... eller de har två olika ... eller de har samma snabbhet fast på två olika sätt. Pernilla: Ja Nasse har mindre lufttryck.

Jim: Luftmotstånd!

Pernilla: Ja och Nalle Puh är tyngre så att han får mer luftmotstånd.

Jim: Ja han får mer luftmotstånd men han är tyngre.

Mattias: Men om vi håller flaskan på andra hållet så (horisontellt).

Gruppmedlemmarna fortsätter att utveckla diskussionen och för in information och relaterar till olika variabler som t.ex. lufttryck, luftmotstånd, massa och hastighet. Dessa olika variabler är relevanta för att förklara fenomenet och leda gruppen till en djupare förståelse. Lottas resonemang 
om föremåls "snabbhet fast på olika sätt" kan ses som ett sätt att beskriva att Nalle Puh och Nasse faller lika fort trots att krafterna på dem är olika och Mattias kvalificerar diskussionen då han ställer nya hypoteser och föreslår kompletterande experiment..

\section{Grupp 3-Nalle, Nasse och Ballonger}

Transkripten visar ett resonemang där dragningskraften relateras till luftmotstånd och densitet med hjälp av att barnen diskuterar beteendet hos ballonger fyllda med luft, vatten och helium:

Jenny: Varför faller saker till marken då vi tappar dem?

Paul: För att de är tyngre än luften...

Kristian: Dragningskraften. Tyngdlagen.

Jenny: Vem når marken först av nalle Puh och Nasse då de hoppar samtidigt?

Colin: Nalle Puh för han är skittung.

Kristian: Han som är tyngst.

Jenny: Varför faller saker till marken då vi tappar dem?

Kristian: Dragningskraften drar dem nedåt.

Colin: För att de är tyngre än luften. Det är därför de faller nedåt.

Jenny initierar diskussionen genom att läsa den fråga som är ställd på pappret. Paul för in begreppen dragningskraft och tyngdkraft. Kristian för in begreppet dragningskraft och ännu en gruppmedlem (Colin) går med i diskussionen. Colins påstående stöder Pauls tidigare uttalande, och bygger även det på vardagsrelaterade begrepp. De fyra diskuterande gruppmedlemmarna visar i dialogen att de gemensamt stödjer två förklaringar till varför saker faller till marken där den ena är att "Dragningskraften drar dem nedåt" och den andra att "De är tyngre än luften". Kristian och Colin vidareutvecklar Pauls tidigare kommentar om tyngdens betydelse. Gruppen har hittat en strategi som verkar vara värdefull för att lösa uppgiften och genom samarbete försöker de nu att lösa den. Någon fortsätter på en idé som en annan har föreslagit och utvecklar denna. I den fortsatta diskussionen om Nalle Puh och Nasse fortsätter gruppmedlemmarna att relatera till olika variabler som är relevanta för att förklara det tänkta fenomenet (luftmotstånd, massa och densitet) och till andra företeelser för att förstå begreppen. Genom att tillägga eller utveckla något av vad en annan gruppmedlem har sagt kvalificerar och vidareutvecklar de samtalet. Resonemanget om luftens betydelse är viktig i diskussionen då luftmotståndet har en stor betydelse för experimentet.

Jenny: Varför åker då ballonger uppåt?

Paul: Ballonger åker väl inte uppåt.

Jenny: De flyger uppåt.

Kristian: Det är väl för att de är ungefär lika tunga som luften...det är därför de åker uppåt. Hanna: Ja men det är ju dragningskraft.

Paul: Det är det inte!

Jenny: Ballongen flyger iväg för att det är luft i den ju. Den flyger ju.

Paul: Ja om det är helium i.

Jenny: Men den flyger ju upp.

Hanna: Inte alla.

Paul: Jo alla med helium i.

Jenny: Det är någonting i Heliumet.

Kristian: Men om man har vatten i. Det är ju så med vattenballonger och de flyger ju ned.

Paul: Men om man har vatten i så har man ju ingen luft i sig.

Jenny: Om det är luft i ballongen så flyger den ju inte, bara om det blåser.

Paul: Men den flyger ju i vilket fall.

Kristian: En vanlig ballong gör ju det.

Hanna: Varför flyger en helium ballong då?

Paul: Helium är lättare än luft.

Jenny: Det är något i Helium som gör att den flyger uppåt. 
Jenny relaterar till ett för henne och de andra känt vardagsfenomen, ballonger. Kristians påstående att ballonger som är lika tunga som luften pekar på att han vill pröva en möjlig förklaringsmodell. Jenny ifrågasätter inte tidigare talares åsikter men relaterar till en annan företeelse för att förstå begreppen då diskussionen med detta får en annan riktning. Att jämföra vattenballonger, ballonger fyllda med luft och heliumballonger visar ett resonemang där eleverna ställer hypoteser, resonerar och problematiserar. Pauls motsägelse på Jennys replik vidareutvecklar och kvalificerar diskussionen då eleverna i gruppen får reflektera över och relatera till andra fenomen som bland annat bygger på begreppet densitet. I diskussionen om heliumballonger och vattenballonger prövar barnen olika begrepp och relaterar dessa till sina egna vardagserfarenheter.

Kristian: Desto mer den väger...

Colin: Den där smala lilla pinnen den kom före det stora feta suddet.

Hanna: Det är bara för att den har mindre luftmotstånd.

Jenny: Vi testar med flaskorna.

Kristian: Jag tror Nalle Puh.

Jenny: Jag med.

Paul: jag tror Nasse.

Kristian: det föll lika!

Jenny: Men det är inte säkert att du släppte samtidigt.

Paul: Så då (Igen).

Kristian: Lika ju.

Jenny: Jag släpper nu.

Hanna: De åker ju samtidigt Nalle Puh och Nasse. De skall komma ned samtidigt.

Diskussionen får en annan karaktär då eleverna börjar testa sina hypoteser. Genom att t.ex. släppa olika föremål för de in stöd och information som antingen styrker eller dementerar deras tidigare påståenden. Deras tidigare hypotes om att den tyngsta faller först, förkastas genom en gemensam erfarenhet. Genom det praktiska experimentet och observationen av detta utvecklar de i dialogen nya variabler som blir relevanta för att förklara fenomenet. Detta leder gruppen till en djupare förståelse. Genom att eleverna i gruppen håller med eller ifrågasätter varandras uttalanden visar de också varandra att det är meningsfullt att försöka förstå världen. Detta hjälper dem också att fortsätta sina försök att skapa egen förståelse genom dialogen. Eleverna uttrycker känsla då de observerar resultatet av experimentet vilken kan bero på ett nyskapande av en gemensam erfarenhet som strider med deras ursprungliga hypotes. Det starka intryck de visar i sin dialog då resultatet inte blev det de förväntade resulterar i en gemensam omarbetning av den ursprungliga hypotetiska förklaringen.

\section{Grupp 4-Gräns för fallhastigheten}

I följande transkript introduceras ett gränsvärdesresonemang:

David: De kom ju samtidigt. Men det var bara för att det var lite mindre vatten i den. Det går snabbare än denna.

Anders: Eller vänta lite. Man kan bara falla en viss hastighet. Det går inte att falla snabbare än den hastigheten.

Roger: Ett sugrör och en tandsticka de har olika snabbheter.

Anders: Men det går inte så. Om man skall falla med den farten så går den inte snabbare än denna.

David: Men dragningskraften drar ju båda.

Anders: Det går inte att falla snabbare än detta och så drar dragningskraften dem båda. Fattar ni?

Magnus: Men denna är ju tyngre och därför borde den gå snabbare.

Anders: Men det är just en hastighet. 
Roger: Men om man släpper tio kilo järn och ett kilo järn... då kommer ju den som är tio kilo snabbare.

Anders: Men Roger, det finns en fart som går och sen går det inte att falla snabbare än just den farten. Dragningskraften påverkar samma.

Roger: Så alla åker så snabbt. Suddet och pennfacket ... vilken kommer först?

David: Pennfacket kom först... det beror ju på när du släpper den... Pennfacket kom först.

Roger (testar): Nej där har du fel. Där har du faktiskt fel. Kolla här nu. Jag tar någonting som helst. Jag tar ett papper.

Anders: Men Roger, den tar ju luften med sig. Det är ju inte samma sak.

Anders, Magnus, Roger och David diskuterar hur fort föremål faller och Anders försöker förklara gränsvärdet för hastigheten genom att tala om att det finns en fart och det går inte att falla snabbare en denna. I detta resonemang för han också in luftmotståndets påverkan då han säger att "den tar ju luften med sig, det är ju inte samma sak". Eleverna relaterar och associerar fenomenet till observationerna av experimenten. I naturvetenskap är ofta begrepp så som reproducerbarhet och felkälla viktiga för att bekräfta ett resultat. Eleverna ifrågasätter sitt resultat att de båda föremålen når marken samtidigt. De diskuterar och resonerar runt det genomförda experimentet på ett sätt där experimentets utfall ger dem en ny insikt och de tvingas organisera om i sina föreställningar. Barnen går utanför de givna ramarna och ställer upp nya hypoteser utöver den givna informationen för att få fram en förklaring eller en tolkning. Olika tankemodeller förs in i diskussionen för att konstruera olika hypotetiska fall där tidigare erfarenheter och vardagskunskaper används.

\section{Diskussion}

Flera forskningsstudier har visat att barns missuppfattningar i mekanik är vanligt förekommande (Clement, 1982; Driver, 1994; Gunstone \& Watts, 1985). Att genomföra praktiska experiment i klassrummet och att relatera dessa till fysikaliska begrepp, har i denna studie visat sig vara ett sätt att få 11-åringar att diskutera fysik på ett mycket engagerat sätt. I sina samtal för de in olika termer och exempel, som kan spåras till andra fysikaliska fenomen än just de som efterfrågas i experimentet. Spontana begrepp växlas med vetenskapliga begrepp, där de spontana begreppen relateras direkt till erfarenheter i barnens omvärld. Det finns en progression i resonemangen som också följer de kategorier som representeras i Barnes \& Todds kognitiva strategier. De resonerar runt problemställningen genom att väcka nya frågor "Varför åker då ballonger uppåt?". De ställer upp hypoteser och diskuterar dessa genom att relaterar dem till tankemodeller och vardagssammanhang. "Men om man skjuter en kanonkula rakt upp och om man skjuter en sten rakt upp. Stenen går fortare rakt upp. Kanonkulan går fortare ned för att den stannar mycket snabbare".

De genomför experimenten och resonerar om och ifrågasätter utfallet "Men det är inte säkert att du släppte samtidigt". Barnen relaterar begreppen gravitation och dragningskraft till experimenten och i sina resonemang går de också ett steg vidare genom att diskutera vad som påverkar de fallande föremålen, varför de når marken samtidigt samt att gravitationen inte påverkar alla föremål på samma sätt. Barnen växlar i sina diskussioner mellan vardagsbegreppet faller ned, dras ned och det vetenskapliga begreppet gravitation. "Det är gravitationen... eller vad det heter. Det är något om gravitation och G-krafter... någonting på jorden som gör att man... de åker ändå lika snabbt ned?" Dragningskraften drar dem nedåt". "För att de är tyngre än luften. Det är därför de faller nedåt". I resonemanget förekommer också exempel där ett barn visar att han även förstått hur gravitationen påverkar föremål "om gravitationen är låg så kan man ju hoppa över taken". Likaså resoneras om luftmotståndets relation till hur fort föremål faller till marken. "Det är... de har ju lika luftmotstånd för att de är lika stora och ser likadana ut." Eleverna för också i sina diskussioner ett intressant resonemang om densitetsbegreppet. Trots att de inte nämner begreppet densitet diskuterar de t.ex. skillnaden mellan ballonger fyllda med helium, luft och vatten. 
"Ballongen flyger iväg för att det är luft i den ju. Den flyger ju". "Men om man har vatten i. Det är ju så med vattenballonger och de flyger ju ned". "Helium är lättare än luft." Ett för 11-åringar förhållandevis avancerat resonemang om densitet, luftmotstånd och gravitation växer fram i flera av diskussionerna då eleverna får möjlighet att fritt resonera om experimenten.

Genom sina resonemang, hur de relaterar vetenskapliga begrepp till vardagserfarenheter, samt för in nya begrepp i diskussionerna och konstruerar hypotetiska fall, visar flera av barnen en förmåga att utveckla sina egna påståenden. Barnen argumenterar sina hypoteser och förklaringar där förståelsen speglas i gemensamma upplevelser och reflekteras genom samtal. Eleverna i de fyra grupperna samarbetar i ett sammanhängande och meningsfullt samtal och tillämpar rationella strategier för att klara av sina uppgifter. Eleverna omarbetar tolkningarna av de praktiska experimenten där deras samarbete öppnar vägen till nya insikter. I diskussionerna söker eleverna efter relationer mellan flera synsätt, samt en överbyggande princip som innehåller båda synsätten.

En ökad förståelse gör det möjligt att tillfälligt gå utanför sin egen kunskapskonstruktion och göra den till objektet för uppmärksamhet. Flera av barnen visar i diskussionerna på en god självkänsla och säkerhet då de argumentera för att få andra att förstå. Analysen visar att elevers förmåga att ta del i sociala förhandlingar och deras förmåga att ta hänsyn till andras synpunkter utvecklas genom dialogen. Kommunikationen i det traditionella klassrummet styrs i stor utsträckning av läraren och dennes frågor. Brittisk forskning har visat att $47 \%$ av lärarens yttrande är frågor mot endast $8 \%$ av elevernas yttranden. Det har även visats att lärarens frågor har en tendens att blockera kommunikationen i klassrummet (Hundeide, 2003). I denna studie deltar alla barn aktivt i diskussionen och finns en dynamisk kvalitet i barnens spontana resonemang som är intressant ur ett undervisningsperspektiv.

Medvetna begrepp tillägnas enligt Vygotsky (1934/1986) genom bearbetning av egna erfarenheter i kombination med undervisning och sådana medvetna begrepp används när något skall bevisas eller förklaras. För att visa en djupare kognitiv förmåga räcker det inte att endast ha förstått själv utan man måste också kunna förklara ett begrepp för någon annan. Eleverna visar i sina samtal att de kan delta i livliga diskussioner utan att kommunicera vetenskapliga begrepp, men om de skall förklara eller bevisa uppkommer behovet av ord och termer och därför är terminologin viktig. Genom att experimentera i klassrummet och på nöjesparken Liseberg kan eleverna relatera vetenskapliga begrepp till sina observationer och upplevelser och initiera en djupare förståelse för mekanik. Att skapa lärandesituationer genom praktiska experiment, att diskutera hypoteser, händelser och resultat, har här visat sig vara ett bra sätt att låta eleverna närma sig fysikens diskurs. Diskursiva gränser överskrids och passeras i diskussionerna och olika fenomen i fysiken berör då barnen använder termer så som gravitation, densitet, luftmotstånd, helium, tryck m.m. Studien visar hur elever uttrycker sig i ord och handling då de angriper olika fysikaliska problem. De växlar mellan vardagligt språk och vetenskapligt språk, genomför sina experiment på ett systematiskt och reflekterande sätt och börjar därmed träda in i fysikdiskursen.

\section{TACK}

Avslutningsvis vill jag tacka de personer som bidragit till utformningen av denna artikel. AnnMarie Pendrill som också har initierat Lisebergsprojektet samt mina handledare Ulla Tebelius, Håkan Pettersson och Ingemar Holgersson. 


\section{REFERENSER}

Andersson, B. (1989). Grundskolans Naturvetenskap. Stockholm: Skolöverstyrelsen och Utbildningsförlaget

Andersson, B. (2001). Elevers tänkande och skolans naturvetenskap. Forskningsresultat som ger nya idéer. Stockholm: Liber

Bagge, S. (2003). Learning physics by experiment - An investigation of extramural learning. Göteborg: Chalmers reproservice.

Bagge, S., \& Pendrill, A-M. (2002). Classical physics experiments in the amusement park. Physics Education, 37(6), 507-511.

Barnes, D., \& Todd, F. (1977). Communication and learning in small groups. London: Routledge \& Kegan Paul Ltd.

Clement, J. (1982). Students pre-conceptions in introductory mechanics. American Journal of physics, 50(1), 66-71.

Driver, R., Squires, A., Rushworth, P. \& Wood-Paulson, V. (1994). Making Sense of Secondary Science. London: Routledge.

Engeström, Y. (1987). Learning by expanding. Helsinki: Orienta-Konsultit Oy.

Falk, J. F., Donovan, E., \& Woods, R. (2001). Free-choice science education - How we learn science outside of school. New York: Colombia University.

Gunstone, R., \& Watts, M. (1985). Force and motion. I R. Driver, E. Guesne, \& A. Tiberghien (Red.), Children's ideas about science (s. 85-104). Milton Keynes: Open University Press.

Gunstone, R., \& White, R. (1981). Understanding of gravity, Science Education, 65(3), 291-299.

Hart, C. (2002). If the sun burns you is that a force? Some definitional prerequisits for understanding Newton's laws, Physics Education, 37(3), 234-238.

Helldén, G. (1992). Grundskoleelevers förståelse av ekologiska processer. Stockholm: Almqvist \& Wiksell.

Hundeide, K. (2003). Det intersubjektiva rummet, I O. Dysthe (Red.), Dialog, samspel och lärande (s 143-166). Lund: Studentlitteratur.

Lave, J. (1997). The culture of acquisition and the practice of understanding. I D. Kirshner \& J.A. Whitson (Red.), Situated cognition: social, semiotic, and psychological perspectives (s 17-35). Mahwah, NJ: Lawrence Erlbaum Associates.

Lemke, J. L. (1990). Talking science. Language, learning and values. Norwood, NJ: Ablex.

Lindahl, B. (2003). Lust att lära naturvetenskap och teknik. Göteborg: Acta Universitatis.

Nilsson, P., Pendrill A-M., \& Pettersson, H. (2004). Learning Physics with the body. Contribution to XI IOSTE Conference, Poland.

Rogoff, B. (2003) The cultural nature of human development. New York: Oxford University Press.

Schoultz, J. (2000). Att samtala om/i naturvetenskap. Kommunikation, kontext och artefakt. Linköping: Linköpings Universitet

Schreiner, C., \& Sjöberg, S. (2004). ROSE - The Relevance of Science Education. Oslo: Unipub.

Sjöberg, S. (2000). Naturvetenskap som allmänbildning - en kritisk ämnesdidaktik. Lund: Studentlitteratur

Säljö, R. (2000). Lärande i praktiken. Stockholm: Bokförlaget Prisma.

Säljö, R., \& Wyndman, (2002). Naturvetenskap som arena för kommunikation - Ett sociokulturellt perspektiv på lärande. I H. Strömdahl (Red.), Kommunicera naturvetenskap i skolan (s 2142). Lund: Studentlitteratur.

Tytler, R., \& Peterson, S. (2003). Tracing Young Children's Scientific Reasoning. Research in Science Education, 33, 433-465.

Vygotsky, L. (1986). Thought and language. (A. Kouzlin, övers.). Cambridge, MA:MIT Press. (Original publicerat 1934.)

Wenger, E. (1998). Communities of practice. Learning, meaning and identity. New York: Cambridge University Press. 